\title{
PENGEMBANGAN MEDIA PEMBELAJARAN INTERAKTIF PADA MATA PELAJARAN BAHASA INGGRIS
}

\author{
Nur Annisa', Abdul Hasan Saragih ${ }^{2}$, R. Mursid ${ }^{3}$ \\ ${ }^{1}$ SD Namira, Medan, Sumatera Utara \\ ${ }^{2,3}$ FT Universitas Negeri Medan, Sumatera Utara \\ nisha_kaka@yahoo.com
}

\begin{abstract}
Abstrak: Penelitian ini bertujuan untuk: menghasilkan media pembelajaran interaktif yang layak digunakan, mudah dipelajari mahasiswa dan dapat dipakai untuk pembelajaran individual, mengetahui keefektifan media pembelajaran interaktif yang dikembangkan pada mata pelajaran Bahasa Inggris. Jenis penelitian ini adalah penelitian pengembangan yang menggunakan model Borg \& Gall yang dipadu dengan model Dick \& Carey. Hasil pengembangan menunjukkan bahwa uji ahli dan uji coba yang dilakukan kualifikasi sangat baik dengan melalui tahapan revisi produk. Metode yang digunakan dalam penelitian adalah kuasi eksperimen. Hasil pengujian hipotesis membuktikan bahwa terdapat perbedaan yang signifikan antara hasil belajar siswa yang dibelajarkan dengan menggunakan media pembelajaran interaktif dengan tanpa media interaktif. Hal ini ditunjukkan dengan hasil pengolahan data dan disimpulkan bahwa hasil belajar kelompok siswa yang dibelajarkan dengan menggunakan media pembelajaran interaktif lebih tinggi dari yang dibelajarkan dengan tanpa menggunakan media pembelajaran interaktif.
\end{abstract}

Kata Kunci: pengembangan media pembelajaran interaktif berbasis komputer, menggambar teknik

Abstract: This study aims to: produce a viable interactive learning media use, easy to learn students and can be used for individual learning, knowing the effectiveness of interactive learning media were developed in English. This type of research is the development of research that uses models Borg \& Gall combined with Dick \& Carey model. Pengebangan results show that the expert test and qualification testing performed very well with through the stages of a product revision. The method used in the study was a quasi-experimental. Hypothesis testing results prove that there is a significant difference between the learning outcomes of students who learned with using the media of interactive not using learning with media of interactive. This is shown by the results of data processing and concluded that the results of the study group of students that learned by using interactive learning media is higher than that learned by not using learning media of interactive.

Keywords: development of a computer -based interactive learning media, english

\section{PENDAHULUAN}

Undang-undang No 20 tahun 2003 tentang sistem pendidikan nasional mengemukakan seiring dengan perubahan paradigma pembelajaran, maka keberhasilan kegiatan pembelajaran dikelas tidak hanya ditentukan oleh faktor pendidik, melainkan sangat dipengaruhi oleh keaktifan peserta didik dengan pendidik sebagai sumber belajar pada lingkungan belajar. Dengan demikian, peserta didik seharusnya tidak belajar dari pendidik saja, tetapi dapat juga belajar dari berbagai sumber belajar yang tersedia dilingkungannya.
Masalah pendidikan yang menjadi perhatian saat ini adalah sebagian besar peserta didik tidak mampu menghubungkan antara apa yang mereka pelajari dengan bagaimana pemanfaatannya dalam kehidupan nyata. Hal ini disebabkan pembelajaran yang mereka terima lebih menonjolkan tingkat hapalan materi tanpa diikuti pemahaman atau pengertian mendalam. Guru mengajar cenderung text-book oriented serta menggunakan media konvensional saja. Peserta didik kesulitan untuk memahami konsep akademik seperti apa yang diajarkan selama ini, yaitu menggunakan sesuatu yang abstrak dengan metode ceramah. Pembelajaran 
yang berorientasi pada target penguasaan materi terbukti hanya mampu mengantarkan siswa mengingat-ingat materi pelajaran dalam waktu yang relatif pendek dan tidak memahami materi secara mendalam

Melihat keterbatasan yang melekat pada media pembelajaran disekolah, maka sudah saatnya media pembelajaran ditingkatkan kualitasnya atau bahkan diganti dengan mengembangkan suatu media pembelajaran yang lebih inovatif sekaligus interaktif, diantaranya adalah media pembelajaran yang dirancang dengan menggunakan bantuan komputer. Sebuah pembelajaran akan menarik perhatian peserta didik jika ada keterpaduan antara pemilihan strategi atau metode pembelajaran dengan media pembelajaran yang sesuai dengan materi pelajaran yang akan disajikan.

Pada pembelajaran di SD Namira tingkat keberhasilan terhadap pembelajaran masih belum maksimal. Sehingga sangat diperlukan adanya daya tarik dalam kegiatan pembelajaran yakni adanya pengembangan media pembelajaran yang akan menciptakan daya tarik siswa untuk belajar

Reigeluth (1983: 20) menyatakan bahwa hasil belajar secara umum dapat dikategorikan menjadi 3 indikator, yakni: 1) efektivitas pembelajaran yang biasanya diukur dari tingkat keberhasilan (prestasi) siswa dari berbagai sudut, 2) efisien pembelajaran yang biasanya diukur dari waktu belajar atau biaya pembelajaran, dan 3) daya tarik pembelajaran yang biasanya diukur dari tendensi siswa ingin belajar secara terus menerus.

Karakteristik dari siswa SD Namira sangat membutuhkan pembelajaran dengan menggunakan kombinasi audio visual. Para peserta didik sangat membutuhkan pembelajaran yang tidak hanya mendengarkan penjelasan dari guru, namun juga sangat dibutuhkan adanya penggunaan media interaktif antara peserta didik dengan media pembelajaran yang telah diterapkan. Oleh sebab itu perlu adanya pengembangan terhadap media pembelajaran sehingga meningkatkan motivasi peserta didik dalam belajar, khususnya dalam pembelajaran Bahasa Inggris. Media yang akan dikembangkan berupa media pembelajaran interaktif. Dengan menggunakan pembelajaran interaktif yang akan meningkatkan motivasi belajar peserta didik, dan peserta didik pun dapat melakukan pembelajaran mandiri.
Penggunaan media dengan menggunakan komputer merupakan salah satu langkah kegiatan pembelajaran interaktif. Sesuai dengan karakteristik peserta didik terutama kemampuan awal peserta didik terhadap komputer sudah baik, siswa tidak merasa sulit untuk mengoperasikan komputer. Pembelajaran dengan media pembelajaran interaktif dapat meningkatkan kemampuan berpikir siswa serta mampu menyerap informasi dengan cepat. Pembelajaran dengan menggunakan media pembelajaran interaktif akan menciptakan kondisi belajar yang berbeda dan tidak monoton yang dapat dikreasikan dengan menampilkan teks, suara, gambar atau video. Ketersediaan media yang biasa digunakan disekolah seperti buku teks, majalah, surat kabar dan papan tulis dapat menimbulkan kebosanan dalam melakukan pembelajaran didalam kelas. Sedangkan media audio dan visual seperti: televisi, radio, video, dan media elektronik seperti komputer. Semua media yang digunakan tersebut belum di manfaatkan secara maksimal.

Kata media berasal dari bahasa Latin dan merupakan bentuk jamak dari kata medium yang secara harfiah dapat diartikan sebagai perantara atau pengantar. Menurut Heinich, Molenda dan Russel (1990) dingkapkan bahwa media is a channel of communication. Derived from the Latin word for "between", the term refers "to anything that carries information between a source and a receiver".

Kata media didefenisikan dengan multi makna, baik dilihat secara terbatas maupun secara luas. Munculnya berbagai macam defenisi disebabkan adanya perbedaan dalam sudut pandang, maksud, dan tujuan. Heinich (1996:5) Media merupakan komunikasi berarti seperti film, televisi, radio, audio, rekaman, foto, diproyeksikan dan sejenisnya adalah media komunikasi. Semuanya itu dianggap media pembelajaran ketika digunakan untuk menyampaikan pesan dalam pembelajaran.

AECT (Association for Education and Communication technology, 1977:201) memaknai media sebagai segala bentuk yang dapat dimanfaatkan dalam proses penyaluran informasi. NEA (National Education Association) memaknai media sebagai segala benda yang dimanipulasi, dilihat, didengar, dibaca, atau dibincangkan beserta instrument yang digunakan untuk kegiatan tersebut.

Miarso (2009) memandang media secara luas dalam system pendidikan sehingga 
mendefinisikan media adalah segala sesuatu yang dapat merangsang terjadinya proses belajar pada diri peserta didik. Masih dalam bahasan mengenai media, para ahli memberikan beberapa pengertian. Sudjana (1991) menjelaskan bahwa media merupakan alat komunikasi dan sumber informasi. Kata media yang berasal dari bahasa latin mengarah kepada segala sesuatu yang membawa informasi dari suatu sumber kepada penerimanya.

$$
\text { Dalam merencanakan }
$$

dan

melaksanakan aktivitas pembelajaran, setiap guru dituntut dapat mempersiapkan dan memfungsikan segala unsur yang menunjang kelancaran proses pembelajaran agar dapat berjalan dengan efektif dan efisien. Dalam salah satu unsur yang menunjang pembelajaran, guru dituntut agar mengetahui dan merancang pemakaian media pembelajaran serta dapat mengetahui fungsi dan kegunaan media tersebut. Menurut sudiman (2003) fungsi atau kegunaan media antara lain : (1) membuat kongkrit konsep yang abstrak, (2) membawa objek yang berbahaya atau sukar didapat kedalam lingkungan belajar, (3) menampilkan objek yang terlalu besar, (4) menampilkan objek yang tidak dapat diamati dengan kasat mata, (5) mengamati gerakan yang terlalu cepat, (6) memungkinkan siswa berinteraksi langsung dengan lingkungannya, (7) memungkinkan kesegaran pengamatan dan persepsi bagi pengamatan belajar siswa, (8) membangkitkan motivasi belajar, (9) menyajikan informasi belajar secara konsisten dan dapat diulangi maupun disimpan menurut kebutuhan, (10) menyajikan pesan atau informasi belajar secara serempak, membatasi batasan waktu maupun ruang, dan (11) mengontrol arah maupun kecepatan belajar siswa.

Dengan demikian media memiliki fungsi yang jelas yaitu memperjelas, memudahkan dan membuat menarik pesan kurikulum yang akan disampaikan oleh guru kepada peserta didik sehingga dapat memotivasi belajarnya dan mengefesienkan proses belajar. Seperti yang dinyatakan Gagne (dalam Raharjo 1991) media sebagai komponen sumber belajar dilingkungan peserta didik yang dapat merangsang peserta didik untuk belajar.

Berdasarkan keahlian pengguna media, media dapat dikelompokkan atas : (1) media yang tidak memerlukan keahlian khusus, misalnya : papan tulis/ white board, transparansi (OHP), bahan cetak (buku, modul, handout), dan (2) media yang memerlukan keahlian khusus yaitu : program audio visual, program slide, Microsoft powerpont, dan Macrmedia flash. Berdasarkan perlu atau tidaknya guru atau tutor dalam menggunakannya, media dapat dikelompokkan atas : (1) yang tergantung hadirnya guru, misalnya : papan tulis/white board, transparansi (OHP), dan (2) media yang tidak bergantung kehadiran guru atau tutor, misalnya : media rekam, bahan belajar mandiri (dapat dipelajari tanpa guru/pengajar). Sejalan dengan itu Hamid (2009:55) mengemukakan bahwa media pembelajaran adalah komponen strategi penyampaian yang dapat dimuati pesan yang akan disampaikan kepada pebelajar, apakah itu orang, alat atau bahan.

Dalam memilih media yang paling tepat, Dick \& Carey (2005) faktor penting dalam pemilihan media pembelajaran, yaitu: (1) ketersediaan media di lingkungan pembelajaram, (2) kesanggupan ahli memproduksi materi pembelajaran untuk digunakan dengan media yang dipilih, (3) fleksibilitas, waktu, dan kecocokan materi dengan media, dan (4) faktor biaya. Disamping kesesuaian dengan perilaku belajarnya, faktor lain yang harus dipertimbangkan dalam pemilihan media yaitu faktor yang menyangkut keluwesan, kepraktisan, dan ketahanan media yang bersangkutan untuk waktu yang lama.

Dari berbagai pengertian diatas dapat disimpulkan bahwa media pembelajaran adalah suatu alat atau metode yang sistematis yang digunakan dalam kegiatan pembelajaran yang memiliki fungsi yaitu memperjelas, memudahkan dan membuat menarik pesan yang akan disampaikan oleh guru kepada siswa sehingga dapat memotivasi belajar siswa dan mengefisienkan proses pembelajaran.

Media interaktif digolongkan sebagai media konstruktifistik yang terdiri dari pembelajaran, siswa, dan proses pembelajaran. Dalam proses pembelajaran teknologi seperti komputer, adalah alat dalam multimedia dan jaringan web terluas didunia yang sangat besar pengaruhnya terhadap siswa dalam proses pembelajaran. Program multimedia interaksi merupakan salah satu media pembelajaran yang berbasis komputer yang mensinergikan semua media yang terdiri dari teks, grafik, foto, video, animasi, musik dan narasi.

Sagala (2003), pembelajaran interaktif mempunyai dua karakteristik yaitu: (1) dalam 
proses pembelajaran melibatkan proses mental siswa secara maksimal, bukan hanya menuntut siswa sekedar mencatat, akan tetapi menghendaki aktivitas siswa dalam proses berpikir, (2) dalam pembelajaran membangun suasana dialogis dan proses tanya jawab terus menerus yang diarahkan untuk memperbaiki dan meningkatkan kemampuan siswa untuk memperoleh pengetahuan yang mereka kontruksi sendiri

Heinich (1997:187) mengemukakan media interaktif merupakan kumpulan materi pembelajaran yang menyertakan lebih dari satu jenis media yang disusun dalam satu topik yang didalamnya terdapat film strip, slide, videotape, rekaman, gambar, OHP, film pendek, peta, lembar kerja, grafik, bagan, brosur, objek nyata dan model.

Menurut Anjani (2013:1) multimedia interaktif adalah suatu media yang sangat kompleks dengan menggabungkan dari beberapa unsur media seperti teks, gambar, grafik, foto, video dan animasi secara berkala sehingga menjadi suatu kumpulan yang menarik dan dapat mengalihkan perhatian untuk melihatnya. Menurut Cheng (2009:204) mengatakan bahwa multimedia interaktif dirancang untuk menawarkan pembelajaran yang interaktif dalam bentuk 3D, grafik, suara, video, animasi dan menciptakan interaksi.

Berdasarkan pengertian tersebut maka dapat disimpulkan bahwa media interaktif adalah suatu tampilan media yang dirancang oleh desainer agar tampilannya memenuhi fungsi menginformasikan pesan dan memiliki interaktifitas kepada penggunanya (user).

Berdasarkan pengertian tersebut maka dapat disimpulkan bahwa media interaktif adalah suatu tampilan media yang dirancang oleh desainer agar tampilannya memenuhi fungsi menginformasikan pesan dan memiliki interaktifitas kepada penggunanya (user).

Karakteristik terpenting pada media pembelajaran interaktif adalah bahwa siswa tidak hanya memperhatikan penyajian atau objek, tetapi dipaksa untuk berinteraksi selama mengikuti pelajaran. Menurut Miarso (2004:465) paling sedikit ada tiga macam interaksi yang dapat diidentifikasi. Pada tingkat pertama siswa berinteraksi dengan sebuah program, misalnya mengisi blanko pada teks yang terprogram. Tingkat berikutnya siswa berinteraksi dengan mesin, misalnya mesin pembelajaran, simulator, laboraturium, atau computer. Bentuk ketiga media interaktif adalah yang mengatur interaksi antar siswa secara teratur tetapi tidak terprogram.

Berdasarkan uraian diatas, istilah media pembelajaran interaktif dapat diartikan sebagai system komunikasi interaktif berbasis computer dalam suatu penyajian secara terintegerasi. Istilah berbasis computer berarti bahwa program media menggunakan computer dalam menyajikan pembelajaran. Sedangkan terintegerasi berarti bahwa media pembelajaran dapat menampilkan teks, gambar, audio, dan video atau animasi dalam satu kali tayangan presentasi.

Berdasarkan pendapat beberapa ahli dapat disimpulkan bahwa pengembangan media pembelajaran interaktif pada mata pelajaran Bahasa Inggris merupakan upaya pemecahan masalah pembelajaran Bahasa Inggris dengan teknologi komputer yang berkembang semakin canggih melalui serangkaian proses desain, produksi, dan evaluasi. Kegiatannya bukan hanya mengembangkan produk pembelajaran Bahasa Inggris secara terpisah tetapi menyangkut mendesain pelajarannya dan pemanfaatannya.

Berdasarkan uraian diatas, banyak hal yang dapat dijadikan sebagai salah satu media pembelajaran, khususnya untuk pembelajaran Bahasa Inggris disekolah. Salah satunya yaitu menggunakan media pembelajarn interaktif yang berisikan materi Bahasa Inggris yang disajikan semenarik mungkin. Maka dari itu peneliti tertarik mengembangkan media pembelajaran interaktif Bahasa Inggris pada materi "Animals (binatang) and colors (warna)" untuk siswa SD kelas IV yang sesuai dan tepat sehingga menambah daya tarik siswa dan memotivasi siswa dalam memahami materi pelajaran. Selain itu untuk membuat kegiatan pembelajaran lebih mengaktifkan siswa, kerjasama siswa, dan meningkatkan kreatifitas siswa SD Namira. Media berbasis komputer merupakan kombinasi tiga elemen suara, gambar dan teks. Memanfaatkan kemajuan teknologi informasi dan komunikasi, diharapkan mampu memecahkan masalah dalam kegiatan pembelajaran. Salah satu media yang sesuai dengan perkembangan teknologi dan yang dapat digunakan dalam proses pembelajaran ini adalah macromedia flash.

Program macromedia flash adalah sebuah program animasi yang telah banyak digunakan oleh para animator untuk 
menghasilkan animasi yang professional. Oleh karena itu, macromedia flash dapat dijadikan sebagai media pembelajaran yang menarik dan interaktif karena di dalamnya terdapat teks, gambar, suara dan animasi. Seluruh siswa dapat berperan aktif dalam proses pembelajaran dengan program macromedia flash memungkinkan siswa belajar mandiri dalam memahami suatu konsep. Dengan begitu, diharapkan standar kompetensi dan kompetensi dasar dapat tercapai. Berdasarkan hal tersebut maka, pada penelitian ini dikembangkan sebuah media pembelajaran berbantuan komputer dengan menggunakan program Macromedia flash yang digunakan dalam proses pembelajaran yang bertujuan untuk meningkatkan minat siswa.

Dalam pengembangan media interaktif ini, software yang dipakai adalah macromedia flash 8.0. Alasan utama mengapa Flash dipilih sebagai authoring tool pada pengembangan media pembelajaran interaktif ini dibanding tool-tool yang lain adalah animasi flash ini berbasi vektor. Ini menguntungkan karena objek vektor dapat diperbesar dan tetap cantik sempurna tidak pecah, juga cepat downloadnya. Animasi Flash mempunyai ukuran file yang jauh lebih kecil dan bersifat streaming. Artinya, begitu sekian byte data awal file telah didownload, animasi dapat langsung dijalankan. Karena ukuran file (swf) nya yang kecil maka ini akan menguntungkan apabila produk penelitian ini kedepan akan diupload atau ditaruh didalam website sekolah sebagai elearning. Kemampuan streaming inilah merupakan salah satu alasan mengapa Flash lebih disukai daripada yang lain.

\section{METODE PENELITIAN}

Penelitian ini dilaksanakan di SD Swasta Namira yang terletak di Jl. Setia Budi Pasar 1 Tanjung Sari No 76 Medan pada siswa kelas IV semester gasal Tahun Ajaran 2015/2016. Waktu pelaksanaan penelitian dimulai pada tanggal 16 Maret sampai pada tanggal 06 April 2016. Metode penelitian yang digunakan adalah research and development (Borg and Gall), karena penelitian ini termasuk penelitian pengembangan pendidikan yang dimaksudkan untuk menghasilkan produk pembelajaran yang layak dimanfaatkan dan sesuai kebutuhan. Model pengembangan merupakan serangkaian prosedur dalam rangka menghasilkan media pembelajaran mata pelajaran Bahasa Inggris. Adapun langkahlangkah dari tahapan pengembangannya adalah sebagai berikut :

1. Melakukan penelitian terlebuh dahulu, yang meliputi :

a. Identifikasi kabutuhan pembelajaran dan menentukan standar kompetensi mata pelajaran

b. Melakukan analisis pembelajaran

c. Mengidentifikasi karakteristik dan perilaku awal peserta didik

d. Menulis kompetensi dasar dan indikatornya

e. Pembuatan desain software

2. Pengumpulan bahan, yang meliputi :

a. Pembuatan dan pengumpulan gambar (image) dan animasi

b. Perekaman dan pengumpulan audio

c. Mengembangkan dan membuat media pembelajaran interaktif

d. Review dan uji coba produk

Analisis data dalam penelitian ini menggunakan analisis deskriptif kuantitatif. Semua data yang terkumpul dianalisis dengan teknik statistik deskriptif yang secara kuantitatif dipisahkan menurut kategori untuk mempertajam penilaian dalam menarik kesimpulan. Data kualitatif yang berupa pernyataan sangat kurang baik, kurang baik, sedang, baik dan sangat baik diubah menjadi data kuantitatif dengan skala nilai 1 sampai 5. Hasilnya dirata-rata dan digunakan untuk menilai kualitas software pembelajaran. Kriteria software akan dikonversikan menjadi nilai dengan skala lima menggunakan Skala Likert yang dianalisis secara deskriptif persentase.

Populasi dalam penelitian ini adalah seluruh siswa kelas IV SD Swasta Namira yang berjumlah 2 kelas yang masing-masing terdiri dari kelas IV A berjumlah 32 orang dan kelas IV $\mathrm{C}$ berjumlah 31 orang dengan jumlah keseluruhan populasi adalah 63 orang.

Dalam penelitian ini data yang diperoleh adalah hasil belajar siswa dari kelas eksperimen dan kelas kontrol. Teknik analisis data yang digunakan adalah teknik deskriptif dan Inferensial. Teknik deskriptif adalah statistik yang digunakan untuk menganalisis data dengan cara menggambarkan data yang telah terkumpul sebagaimana adanya tanpa bermaksud membuat kesimpulan yang berlaku untuk umum atau generalisasi. Misalnya penyajian data menggunakan table, grafik, 
diagram lingkaran, pictogram, perhitungan modus, median, mean, desil, persentil, rata-rata, standar defiasi, porsentasi, korelasi, dan regresi tanpa pengujian signifikasi. Dan teknik inferensial adalah teknik statistik untuk menganalisis data sampel data dan hasilnya diberlakukan untuk populasi. Suatu kesimpulan dari data sampel yang akan diberlakukan untuk populasi itu mempunyai peluang kesalahan dan kebenaran (kepercayaan).

Hipotesis penelitian yang akan diuji adalah :

Ho $: \bar{X}_{1} \leq \bar{X}_{2}$

Ha $: \bar{X}_{1}>\bar{X}_{2}$

$\bar{X}_{1}$ : Rata-rata hasil Belajar Bahasa Inggris siswa yang diajar dengan menggunakan media pembelajaran interaktif.

$\bar{X}_{2}$ : Rata-rata hasil Belajar siswa tanpa media pembelajaran interaktif.
Untuk uji hipotesis digunakan rumus uji dua pihak. Kriteria pengujian terima Ha jika $t_{\text {hitung }}>\mathrm{t}_{\text {tabel }}$ yang didapat dari daftar distribusi $\mathrm{t}$ dengan $\mathrm{dk}=(\mathrm{n}-1)$ dan taraf $\alpha=5 \%$. Untuk melihat nilai keefektifan media pembelajaran interaktif yang dieksperimenkan digunakan rumus perhitungan efektifitas.

\section{HASIL DAN PEMBAHASAN \\ Data Hasil Uji Coba Tahap II Uji Coba Perorangan}

Uji coba perorangan dilakukan pada 3 mahasiswa yang terdiri dari 1 siswa yang memiliki prestasi tinggi, 1 orang yang berprestasi sedang dan 1 orang yang berprestasi rendah. Tujuan uji coba perorangan ini adalah mengidentifikasi kelemahan pembelajaran setelah ditinjau ulang oleh tenaga ahli.

Tabel 1. Skor Penilaian Media Pembelajaran Interaktif Bahasa Inggris Pada Uji Coba Perorangan Tentang Kualitas Materi Pembelajaran

\begin{tabular}{llccccccc}
\hline \multirow{2}{*}{ No } & \multirow{2}{*}{ Indikator Penilaian } & \multicolumn{3}{c}{ Responden } & Jumlah & Persentase & \multirow{2}{*}{ Kriteria } \\
\cline { 3 - 5 } & & $\mathbf{1}$ & $\mathbf{2}$ & $\mathbf{3}$ & Skor & Rata-rata & \\
\hline 1 & Kesesuaian materi & 5 & 4 & 4 & 13 & $86.67 \%$ & Sangat Layak \\
2 & Kejelasan petunjuk belajar & 4 & 4 & 5 & 13 & $86.67 \%$ & Sangat Layak \\
3 & Kemudahan memahami kalimat pada teks & 5 & 4 & 5 & 14 & $93.33 \%$ & Sangat Layak \\
4 & Kemudahan memahami pembelajaran & 5 & 5 & 4 & 14 & $93.33 \%$ & Sangat Layak \\
5 & Ketepatan urutan penyajian & 4 & 5 & 4 & 13 & $86.67 \%$ & Sangat Layak \\
6 & Kecukupan latihan & 4 & 4 & 4 & 12 & $80.00 \%$ & Layak \\
7 & Kejelasan umpan balik & 4 & 4 & 4 & 12 & $80.00 \%$ & Layak \\
8 & Bantuan belajar dengan program & 5 & 5 & 4 & 14 & $93.33 \%$ & Sangat Layak \\
\hline \multicolumn{2}{c}{ Rata-rata Total } & & & & $87.50 \%$ & Sangat Layak \\
\hline
\end{tabular}

Tabel 1 menunjukkan tanggapan 7 kualitas materi dan secara keseluruhan siswa pada uji coba perorangan untuk aspek dinyatakan dalam kriteria "Sangat Baik".

Tabel 2. Skor Penilaian Media Pembelajaran Interaktif Bahasa Inggris Pada Uji Coba Perorangan Tentang Aspek Kualitas Teknis/Tampilan

\begin{tabular}{|c|c|c|c|c|c|c|c|}
\hline \multirow{2}{*}{ No } & \multirow{2}{*}{ Indikator Penilaian } & \multicolumn{3}{|c|}{ Responden } & \multirow{2}{*}{$\begin{array}{c}\text { Jumlah } \\
\text { Skor }\end{array}$} & \multirow{2}{*}{$\begin{array}{c}\text { Persentase } \\
\text { Rata-rata }\end{array}$} & \multirow{2}{*}{ Kriteria } \\
\hline & & 1 & 2 & 3 & & & \\
\hline 1 & Keindahan tampilan layar & 5 & 4 & 5 & 14 & $93.33 \%$ & Sangat Layak \\
\hline 2 & Keterbacaan teks & 4 & 5 & 5 & 14 & $93.33 \%$ & Sangat Layak \\
\hline 3 & $\begin{array}{l}\text { Kualitas gambar dan } \\
\text { animasi }\end{array}$ & 5 & 4 & 5 & 14 & $93.33 \%$ & Sangat Layak \\
\hline 4 & Komposisi warna & 5 & 4 & 5 & 14 & $93.33 \%$ & Sangat Layak \\
\hline 5 & Navigasi & 4 & 4 & 4 & 12 & $80.00 \%$ & Layak \\
\hline 6 & Daya dukung musik & 5 & 4 & 4 & 13 & $86.67 \%$ & Sangat Layak \\
\hline 7 & Interaksi & 4 & 4 & 4 & 12 & $80.00 \%$ & Layak \\
\hline \multicolumn{6}{|c|}{ Rata-rata Total } & $88.57 \%$ & Sangat Layak \\
\hline
\end{tabular}


Tanggapan siswa pada uji coba perorangan ditunjukkan pada Tabel 2 dijelaskan bahwa media pembelajaran interaktif dari aspek kualitas teknis atau tampilan mayoritas dinilai secara keseluruhan dinilai "Sangat Layak".

\section{Data Hasil Uji Coba Tahap III Uji Coba Kelompok Kecil}

Uji coba kelompok kecil dilakukan terhadap 9 orang mahasiswa yang terdiri dari 3 siswa yang berprestasi tinggi, 3 siswa yang berprestasi sedang, dan 3 siswa yang berprestasi rendah dimaksudkan untuk mengetahui beberapa kelemahan atau hambatan yang dihadapi ketika produk media pembelajaran interaktif digunakan.

Tabel 3. Skor Penilaian Media Pembelajaran Interaktif Bahasa Inggris Uji Coba Kelompok Kecil Pada Aspek Kualitas Materi pembelajaran

\begin{tabular}{|c|c|c|c|c|c|c|c|c|c|}
\hline \multirow{2}{*}{ No } & \multirow{2}{*}{ Indikator Penilaian } & \multicolumn{5}{|c|}{ Skor } & \multirow{2}{*}{$\begin{array}{c}\text { Jumlah } \\
\text { Skor }\end{array}$} & \multirow{2}{*}{$\begin{array}{c}\text { Persentase } \\
\text { Rata-rata }\end{array}$} & \multirow{2}{*}{ Kriteria } \\
\hline & & 1 & 2 & 3 & 4 & 5 & & & \\
\hline 1 & Kesesuaian materi & & & & 1 & 8 & 44 & $97.78 \%$ & Sangat Layak \\
\hline 2 & Kejelasan petunjuk belajar & & & & 1 & 8 & 44 & $97.78 \%$ & Sangat Layak \\
\hline 3 & $\begin{array}{l}\text { Kemudahan memahami } \\
\text { kalimat pada teks }\end{array}$ & & & & 1 & 8 & 44 & $97.78 \%$ & Sangat Layak \\
\hline 4 & $\begin{array}{l}\text { Kemudahan memahami } \\
\text { pembelajaran }\end{array}$ & & & & 2 & 7 & 43 & $95.56 \%$ & Sangat Layak \\
\hline 5 & $\begin{array}{l}\text { Ketepatan urutan } \\
\text { penyajian }\end{array}$ & & & & 2 & 7 & 43 & $95.56 \%$ & Sangat Layak \\
\hline 6 & Kecukupan latihan & & & & 3 & 6 & 42 & $93.33 \%$ & Sangat Layak \\
\hline 7 & Kejelasan umpan balik & & & & 2 & 7 & 43 & $95.56 \%$ & Sangat Layak \\
\hline 8 & $\begin{array}{l}\text { Bantuan belajar dengan } \\
\text { program }\end{array}$ & & & & 1 & 8 & 44 & $97.78 \%$ & Sangat Layak \\
\hline \multicolumn{6}{|c|}{ Rata-rata Total } & & & $96.39 \%$ & Sangat Layak \\
\hline
\end{tabular}

Penilaian pada aspek kualitas materi secara keseluruhan dalam kriteria "Sangat pembelajaran untuk uji coba kelompok kecil yang tampak pada Tabel 3 menunjukkan bahwa Baik".

Tabel 4. Skor Penilaian Media Pembelajaran Interaktif Bahasa Inggris Uji Coba Kelompok Kecil Pada Aspek Kualitas Teknis atau Tampilan

\begin{tabular}{llccccccc}
\hline \multirow{2}{*}{ No } & \multirow{2}{*}{ Indikator Penilaian } & \multicolumn{3}{c}{ Skor } & & Jumlah & Persentase & \multirow{2}{*}{ Kriteria } \\
\cline { 3 - 7 } & $\mathbf{1}$ & $\mathbf{2}$ & $\mathbf{3}$ & $\mathbf{4}$ & $\mathbf{5}$ & Skor & Rata-rata & \\
\hline 1 & Keindahan tampilan layar & & & 2 & 7 & 43 & $95.56 \%$ & Sangat Layak \\
2 & Keterbacaan teks & & & 1 & 8 & 44 & $97.78 \%$ & Sangat Layak \\
3 & Kualitas gambar dan animasi & & & 2 & 7 & 43 & $95.56 \%$ & Sangat Layak \\
4 & Komposisi warna & & 2 & 7 & 43 & $95.56 \%$ & Sangat Layak \\
5 & Navigasi & & 2 & 7 & 43 & $95.56 \%$ & Sangat Layak \\
6 & Daya dukung musik & & 3 & 6 & 42 & $93.33 \%$ & Sangat Layak \\
7 & Interaksi & 1 & 2 & 6 & 41 & $91.11 \%$ & Sangat Layak \\
\hline \multicolumn{2}{r}{} & Rata-rata Total & & & & & $94.92 \%$ & Sangat Layak \\
\hline
\end{tabular}

Data Hasil Uji Coba Tahap IV Uji Coba Lapangan

Uji coba lapangan dilakukan terhadap siswa teridiri dari 32. Uji coba lapangan menghasilkan data-data yang nantinya akan mengukur kelayakan dari produk yang dikembangkan, serta untuk mengetahui bagaimana manfaat produk tersebut bagi pemakainya. 
Tabel 5. Skor Penilaian Media Pembelajaran Interaktif Bahasa Inggris Uji Coba Lapangan Pada Aspek Kualitas Materi Pembelajaran

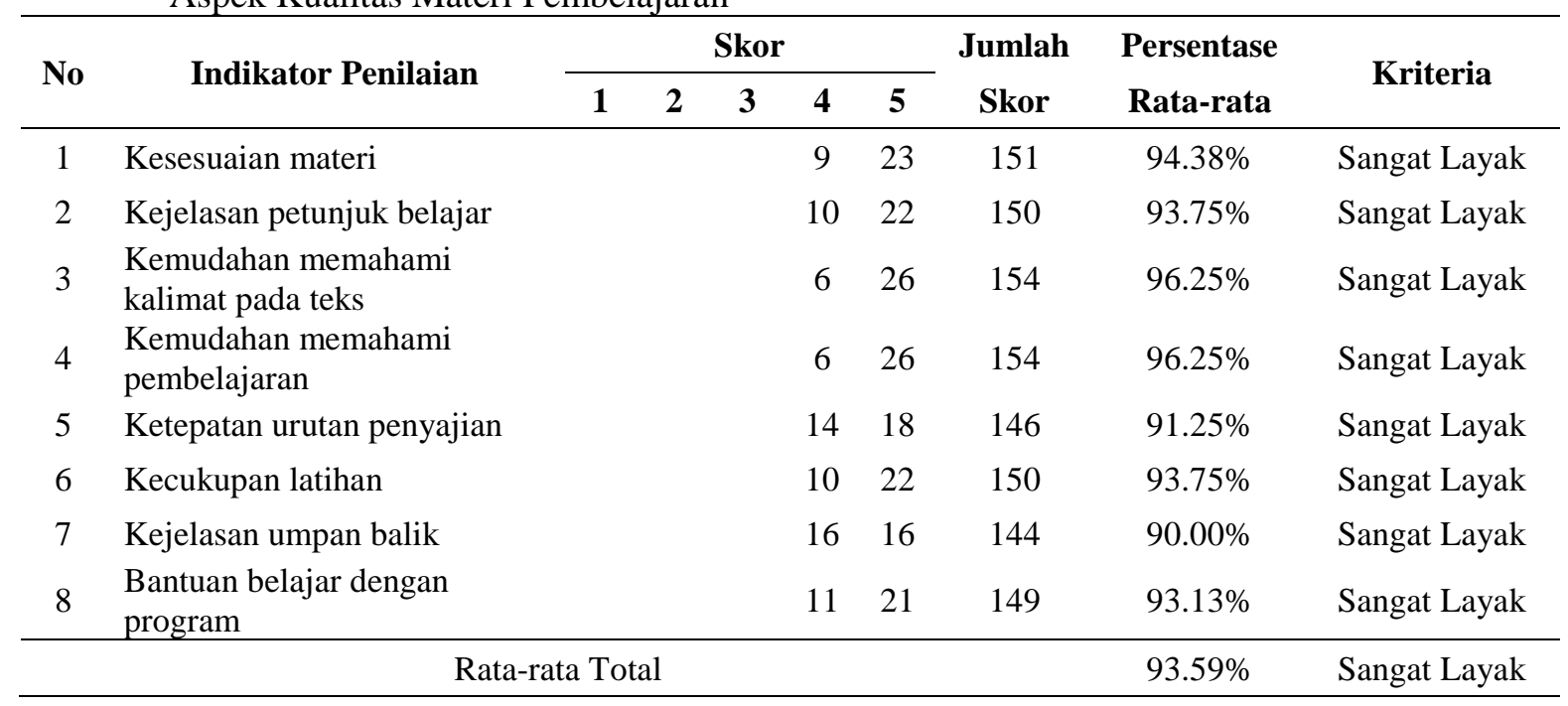

Hasil evaluasi terhadap media pada aspek kualitas teknis atau tampilan untuk pembelajaran pada aspek kualitas teknis atau uji coba lapangan dan keseluruhannya dalam tampilan menunjukkan hasil tanggapan siswa kriteria "Sangat Layak".

Tabel 6. Skor Penilaian Media Pembelajaran Interaktif Bahasa Inggris Uji Coba Lapangan Pada Aspek Kualitas Teknis atau Tampilan

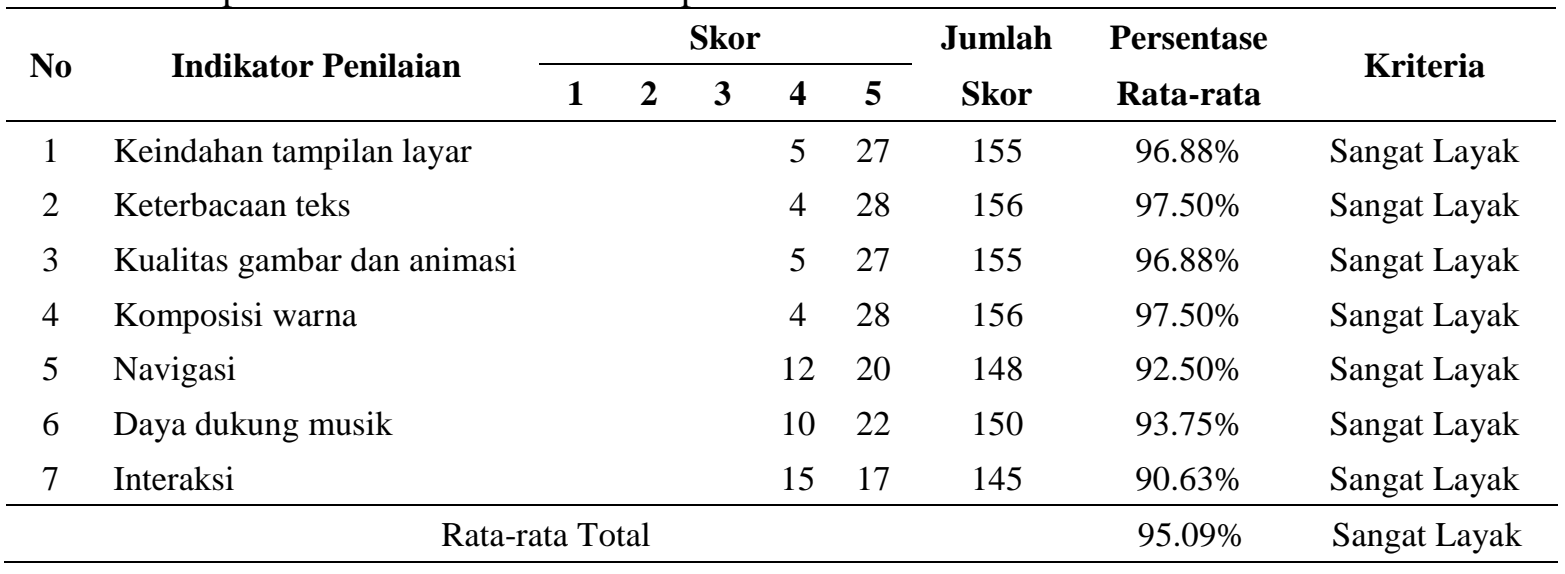

Hasil penilaian uji coba lapangan terhadap aspek kualitas materi pembelajaran pada media pembelajaran interaktif Bahasa Inggris menyatakan bahwa untuk aspek kualitas

Analisis Data Hasil Uji Coba Tahap II Uji Coba Perorangan

Tabel 7. berikut menunjukkan persentase rata-rata hasil penilaian pada uji coba peorangan terhadap aspek kualitas materi materi pembelajaran pada uji coba lapangan menunjukkan 32 orang (95.09\%) menyatakan "Sangat Baik".

pembelajaran sebesar $87,50 \%$ dan aspek kualitas atau teknis tampilan sebesar dan $88,57 \%$ dan masing-masing termasuk kategori sangat layak. 
Tabel 7. Persentase Rata-Rata Hasil Penilaian Terhadap Media Pembelajaran Interaktif Bahasa Inggris Pada Uji Coba Perorangan

\begin{tabular}{cccc}
\hline No & Kategorisasi & $\begin{array}{c}\text { Persentase } \\
\text { Rata-rata }\end{array}$ & Kriteria \\
\hline 1 & Aspek Kualitas Materi Pembelajaran & $87.50 \%$ & Sangat Layak \\
2 & Aspek Kualitas Teknis/Tampilan & $88.57 \%$ & Sangat Layak \\
\hline \multicolumn{2}{c}{ Rata-rata Total } & $88.04 \%$ & Sangat Layak \\
\hline
\end{tabular}

Analisis Data Hasil Uji Coba Tahap III Uji Coba Kelompok Kecil.

Tabel 8. berikut menunjukkan persentase rata-rata dari hasil penilaian terhadap media pembelajaran interaktif berbasis komputer pada matakuliah menggambar teknik pada uji coba kelompok kecil terhadap aspek kualitas materi pembelajaran adalah sebesar $96.39 \%$ dan aspek kualitas teknis atau tampilan sebesar $94.92 \%$ dan masing-masing termasuk kategori sangat layak.

Tabel 8. Persentase Rata-Rata Hasil Penilaian Terhadap Media Pembelajaran Interaktif Bahasa Inggris Pada Uji Coba Kelompok Kecil

\begin{tabular}{cccc}
\hline No & Kategorisasi & $\begin{array}{c}\text { Persentase } \\
\text { Rata-rata }\end{array}$ & Kriteria \\
\hline 1 & Aspek Kualitas Materi Pembelajaran & $96.39 \%$ & Sangat Layak \\
2 & Aspek Kualitas Teknis/Tampilan & $94.92 \%$ & Sangat Layak \\
\hline \multicolumn{2}{c}{ Rata-rata Total } & $95.65 \%$ & Sangat Layak \\
\hline
\end{tabular}

\section{Analisis Data Hasil Uji Coba Tahap IV Uji Coba Lapangan}

Tabel 9. Persentase Rata-Rata Hasil Penilaian Terhadap Media Pembelajaran Interaktif Bahasa Inggris Pada Uji Coba Lapangan

\begin{tabular}{cccc}
\hline No & Kategorisasi & $\begin{array}{c}\text { Persentase } \\
\text { Rata-rata }\end{array}$ & Kriteria \\
\hline 1 & Aspek Kualitas Materi Pembelajaran & $93.59 \%$ & Sangat Layak \\
2 & Aspek Kualitas Teknis/Tampilan & $95.09 \%$ & Sangat Layak \\
\hline \multicolumn{2}{c}{ Rata-rata Total } & $94.34 \%$ & Sangat Layak \\
\hline
\end{tabular}

\section{Pengujian Hipotesis.}

Setelah dilakukan uji kelayakan data selesai maka selanjutnya dilakukan uji $\mathrm{t}$ pretes penelitian. Hal ini dilakukan untuk mengetahui apakah terdapat perbedaan kemampuan awal kelas kontrol dan kelas eksperiman dengan menggunakan uji $\mathrm{t}$ pretes. Berdasarkan hasil perhitungan pada diperoleh output $t_{\text {Hitung }}$ sebesar 5,15 dan dikonsultasikan dengan nilai $\mathrm{t}_{\text {Tabel }}$ pada taraf signifikansi 5\% dan $\mathrm{dk}=61$ sebesar 2,00 dengan statistik Ho diterima apabila $t_{\text {Hitung }}$ $<\mathrm{t}_{\text {Tabel }}$ dan Ho ditolak untuk kondisi sebaliknya. Oleh karena harga $\mathrm{t}_{\text {hitung }} 5,15>\mathrm{t}_{\text {Tabel }} 2,00$ maka dapat ditarik kesimpulan bahwa Ho ditolak dan sekaligus menerima $\mathrm{Ha}$ yaitu hasil belajar Bahasa Inggris siswa yang diajar dengan menggunakan media pembelajaran interaktif lebih tinggi dari hasil belajar Bahasa Inggris siswa yang diajar tanpa media pembelajaran interaktif. Berdasarkan hasil penelitian ini, ratarata nilai siswa yang diajar dengan menggunakan media pembelajaran interaktif lebih tinggi yaitu 79,84 dibandingkan dengan rata-rata nilai siswa yang diajar tanpa media pembelajaran interaktif yaitu sebesar 65,81 .

Ho

$$
\begin{aligned}
& : \bar{X}_{1} \leq \bar{X}_{2} \\
& \text { Yaitu: Rata-rata hasil belajar Bahasa } \\
& \text { Inggris kelompok siswa yang diajar } \\
& \text { dengan menggunakan media } \\
& \text { pembelajaran interaktif lebih rendah }
\end{aligned}
$$


atau sama dengan hasil belajar Bahasa Inggris kelompok siswa yang diajar tanpa menggunakan media pembelajaran interaktif

$\mathrm{Ha}$

$$
: \bar{X}_{1}>\bar{X}_{2}
$$

Yaitu: Rata-rata hasil belajar Bahasa Inggris kelompok siswa yang diajar dengan menggunakan media pembelajaran interaktif lebih tinggi dari hasil belajar Bahasa Inggris kelompok siswa yang diajar tanpa menggunakan media pembelajaran interaktif

\section{PEMBAHASAN}

Media pembelajaran interaktif menyediakan peluang bagi pendidik untuk mengembangkan teknik pembelajaran sehingga menghasilkan hasil yang maksimal. Demikian juga bagi peserta didik, dengan media pembelajaran interaktif diharapkan mereka akan lebih mudah untuk menentukan dengan apa dan bagaimana siswa dapat menyerap informasi secara cepat dan efisien. Sumber informasi tidak lagi terfokus pada teks dari buku tetapi lebih luas dari itu seperti penggunaan computer atau laptop sebagai sumber informasi. Kemampuan teknologi media yang semakin baik dan berkembang akan menambah kemudahan dalam mendapatkan pengetahuan siswa. Sagala (2003) menjelaskan bahwa pembelajaran interaktif mempunyai dua karakteristik yaitu: (1) dalam proses pembelajaran melibatkan proses mental siswa secara maksimal, bukan hanya menuntut siswa sekedar mencatat, akan tetapi menghendaki aktivitas siswa dalam proses berpikir, (2) dalam pembelajaran membangun suasan dialogis dan proses Tanya jawab terus menerus yang diarahkan untuk memperbaiki dan meningkatkan kemampuan siswa untuk memperoleh pengetahuan yang mereka kontruksi sendiri. Produk pengembangan media pembelajaran interaktif pada mata pelajaran Bahasa Inggris ini adalah salah satunya dan merupakan materi pelajaran yang telah dikembangkan dengan memperhatikan aspek pembelajaran dan media sebagai prinsip desain pesan pembelajaran. Penelitian pengembangan produk yang dilakukan ini diarahkan untuk menghasilkan suatu produk berupa media pembelajaran interaktif pada mata pelajaran Bahasa Inggris untuk siswa SD khususnya SD Swasta Namira yang digunakan untuk meningkatkan kualitas proses pembelajaran dan kompetensi siswa.

Berdasarkan data hasil validasi ahli materi, ahli desain pembelajaran dan ahli rekayasa perangkat lunak diperoleh penilaian dengan kriteria sangat layak dengan beberapa saran perbaikan. Selanjutnya data hasil uji coba yang dilakukan terhadap siswa yang meliputi uji coba perorangan, uji coba kelompok kecil dan uji coba lapangan diperoleh hasil penilaian dengan kriteria sangat layak. Secara keseluruhan hasil validasi uji coba pengembangan media pembelajaran interaktif ini memperoleh penilaian sangat layak yang berarti bahwa media pembelajaran interaktif pada mata pelajaran Bahasa Inggris sangat layak digunakan untuk meningkatkan kualitas proses pembelajaran dan kompetensi siswa. Media pembelajaran interaktif pada proses pembelajaran sudah layak untuk digunakan sebagai salah satu alternatif media pembelajaran yang telah ada.

Hal ini didukung oleh penemuan sebelumnya Lingin (2012:53) yang menyatakan bahwa penggunaan media pembelajaran interaktif dengan menggunakan macromedia flash layak untuk digunakan dimana didalam media pembelajaran banyak disisipkan animasi media sehingga menimbulkan ketertarikan pada siswa untuk belajar. Penggunaan media pembelajaran interaktif layak dalam hal berikut: (1) layak dalam hhal kepraktisan, misalnya siswa sebagai user mampu dengan menggunakan media pembelajaran dengan mengikuti semua perintah yang ada dalam media pembelajaran interaktif dan mengefisiensikan waktu dalam hal menjelaskan materi pembelajaran.

Penggunaan media pembelajaran intteraktif akan memotivasi siswa untuk mengulang kembali materi pembelajaran dengan menggunakan media interaktif sehingga mempercepat pemahaman siswa terhadap materi pembelajaran Bahasa Inggris. (2) layak dalam hal teknis, misalnya layak dalam penyampaian materi, yaitu dengan menggunakan media pembelajaran interaktif materi yang disampaikan sesuai dengan kebutuhan para siswa dan sesuai dengan kurikulum pembelajaran yang telah ditetapkan oleh pemerintah serta dengan penggunaan media pembelajaran interaktif dapat memperjelas materi pembelajaran sehingga mudah dipahami oleh semua siswa serta (3) 
layak dalam hall visual atau tampilan media pembelajaran interaktif akan menciptakan desain, animasi yang menarik sehingga akan memotivasi.

Selanjutnya, hasil penelitian Susana (2013), menyimpulkan bahwa multimedia yang dikembangkan membentuk mental untuk belajar secara mandiri dan menyenangkan serta membangun konsep belajar untuk dirinya sendiri, sehingga penggunaan multimedia dalam pembelajaran ini menunjukkan antusias siswa untuk belajar, pengulangan dalam pembelajaran, siswa tidak malu belajar, dan juga terjadi perubahan tingkah laku yang besar, sehingga guru berperan sebagai fasilitator.

Manfaat penggunaan media pembelajaran interaktif pada mata pelajaran Bahasa Inggris adalah sebagai berikut: (1) materi mudah dipahami karena konsep yang disajikan direncanakan untuk mempermudah siswa dan sistematis; (2) media pembelajaran interaktif pada mata pelajaran Bahasa Inggris memberi kesempatan siswa untuk belajar sesuai dengan kecepatan masing-masing individu; (3) belajar lebih cepat dan menarik sehingga tidak menimbulkan kejenuhan karena dilengkapi dengan gambar-gambar dan animasi serta soal latihan yang bervariasi; (4) media pembelajaran interaktif ini juga dapat digunakan sebagai alternatif media pembelajaran secara individu.

Berdasarkan hasil analisis data penelitian penggunaan media pembelajaran interaktif dalam meningkatkan efektifitas pembelajaran siswa, terdapat perbedaan yang signifikan rata-rata hasil belajar Bahasa Inggris siswa yang dibelajarkan dengan menggunakan media pembelajaran interaktif dan siswa yang dibelajarkan tanpa menggunakan media pembelajaran interaktif. Hasil pengujian dengan uji $\mathrm{t}$ menunjukkan harga $\mathrm{t}_{\text {hitung }} 5,15>\mathrm{t}_{\text {Tabel }} 2,00$ yang berarti bahwa hasil belajar Bahasa Inggris siswa yang diajar dengan menggunakan media pembelajaran interaktif lebih tinggi dari hasil belajar Bahasa Inggris siswa yang diajar tanpa media pembelajaran interaktif.

Berdasarkan hasil penelitian ini juga diperoleh data rata-rata nilai siswa yang diajar dengan menggunakan media pembelajaran interaktif lebih tinggi yaitu 79,84 dibandingkan dengan rata-rata nilai siswa yang diajar tanpa media pembelajaran interaktif yaitu sebesar 65,81. Maka, media yang dihasilkan adalah layak dan efektif untuk digunakan dalam pembelajaran. Hasil penelitian ini juga selaras dengan penelitian yang dilakukan oleh Rasien (2010), tentang Penggunaan Media Pembelajaran Interaktif berbasis computer dan sikap inovatif terhadap hasil belajar TIK yang menemukan bahwa siswa yang diajar dengan menggunakan media pembelajaran interaktif berbasis computer memperoleh hasil belajar yang lebih baik khususnya pada mata pelajaran TIK.

Melalui penggunaan media pembelajaran interaktif, siswa diajak untuk belajar dengan pengalaman nyata dan mampu merangsang gairah belajar siswa sehingga para siswa terhindar dari kejenuhan belajar. Relevan dengan penemuan tersebut, Gagne (dalam Raharjo 1991) juga menjelaskan bahwa media sebagai komponen sumber belajar dilingkungan peserta didik, dapat merangsang peserta didik untuk belajar. Media interaktif yang dikembangkan dalam mata pelajaran Bahasa Inggris ini juga terbukti memberikan solusi belajar bagi siswa dimana selain digunakan secara massal di dalam kelas, media interaktif ini juga dapat digunakan siswa secara mandiri atau individu sehingga kegiatan belajar siswa tidak hanya berlangsung di dalam kelas akan tetapi dimana saja. Oleh demikian, sangatlah penting bagi sekolah-sekolah untuk dapat menggunakan media pembelajaran interaktif di dalam proses pembelajaran.

\section{PENUTUP}

Berdasarkan rumusan, tujuan, hasil dan pembahasan penelitian pengembangan media pembelajaran interaktif bahasa inggris yang dikemukakan sebelumnya maka dapat disimpulkan sebagai berikut:

1. Berdasarkan rumusan, tujuan, hasil dan pembahasan penelitian pengembangan media pembelajaran interaktif berbasis komputer yang dikemukakan sebelumnya maka dapat Hasil validasi dari ahli materi, ahli desain pembelajaran, ahli rekayasa perangkat lunak dan uji coba siswa menyatakan bahwa media pembelajaran interaktif dalam pembelajaran Bahasa Inggris yang dihasilkan sangat layak dan efektif digunakan pada pembelajaran Bahasa Inggris dalam meningkatkan hasil belajar siswa

2. Hasil belajar Bahasa Inggris siswa yang diajar dengan menggunakan media pembelajaran interaktif lebih tinggi dari hasil belajar Bahasa Inggris siswa yang 
diajar tanpa media pembelajaran interaktif yang teruji melalui uji statistik $\mathrm{t}$ dengan hasil pengujian menunjukkan harga $t_{\text {hitung }} 5,15>$ $\mathrm{t}_{\text {Tabel }}$ 2,00. Berdasarkan hasil penelitian ini juga diperoleh data rata-rata nilai siswa yang diajar dengan menggunakan media pembelajaran interaktif lebih tinggi yaitu 79,84 dibandingkan dengan rata-rata nilai siswa yang diajar tanpa media pembelajaran interaktif yaitu sebesar 65,81 .

\section{DAFTAR PUSTAKA}

AECT, 1977, Defenisi Teknologi Pendidikan (satuan tugas defenisi \& terminologi AECT). Jakarta: Rajawali.

Borg, W. \& Gall, M.D 2005.Applying Educational Research (5 th Ed). USA

Cheng, G. 2009. Using game making pedagogy to facilitate student learning of interactive multimedia. Australia: Australasian Journal of Educational Technology

Dick, W. dan Carey, I. 2005.The Systemic Design of Instruction. United States of America : Scott Foresman and Company

Gagne, Robert M and Briggs, Leslie J. (1979). Principles of Instructional Design (2nd $E d$.$) . New York: Holt, Rinehart and$ Winston.

Hakim, Lukmanul. (2003). Teknik jitu menguasai macromedia flash MX 2004. Jakarta: Elex Media Komputindo.

Hamid, A. 2009. Teori Belajar dan Pembelajaran. Bandung: Alfa Beta

Heinich, Robert, et. Al. 1996. Instructional Media and Technologies for Learning $\left(\begin{array}{ll}5 t h & e d\end{array}\right)$. New Jersey: A Simon \& Schuster Company Engelewood Cliffs.

Herman Dwi Surjono \& Heni Rita Susila 2009. Pengembangan Media pembelajaran bahasa Inggris untuk SMK. Jurnal Pendidikan Vokasi 45-52. Fakultas Teknik UNY, FKIP Universitas Baturaja.

Linda Kartika Sari \& Dimas Sasongko 2013.Media Pembelajaran Interaktif Bahasa Inggris untuk Siswa Sekolah Dasar.Jurnal Vol 2 No 1-Maret 2013 ISSN : 2302-1136. Program Studi Teknik Informatika, Universitas Surakarta.

Lingin 2012.Pengembangan Media Pembelajaran Interaktif pada Mata Pelajaran Geografi.Jurnal Pendidikan Teknologi 22-30. Teknologi Pendidikan PPs Universitas Negeri Medan.
Miarso, Yusufhadi. 2009. Menyemai Benih Teknologi Pendidikan (Ed. 1) Cet. Ke-4. Jakarta: Kencana

Purwanto. (2009). Evaluasi Hasil Belajar. Yogyakarta: Pustaka Belajar

Reigeluth, C.M. 1983. Instructional Design Theories and Model. London: Lawrence Erlbaum Associates Publisher

Richey, R. 1986. The Theoritical and Conceptual Bases of Instructional Design. New York. Nicholas Publishing Company

Rusman, dkk.2011. Pembelajaran Berbasis Teknologi Informasi dan Komunikasi. Jakarta: Rajawali Persada

Sadiman, A. dkk.2003 Media Pendidikan: Pengertian, Pengembangan dan Pemanfatannya. Jakarta. Seri pustaka Teknologi pendidika No.6 Rajawali

Sagala, S. 2011. Konsep dan Makna Pembelajaran. Bandung: Alfa Beta

Seels, B. B., \& Richey, R. C. (1994). Instructional technology; The definition and domain of the field. Washington DC: Association for Education Communication and Technology.

Sudijono, Anas. (1996). Pengantar evaluasi pendidikan. Jakarta: Raja Grafindo Persada.

Sudjana, Nana. (2004). Penilaian Hasil Proses Belajar Mengajar. Bandung : Rosdakarya.

Sugiyono. (2008). Metode Penelitian Pendidikan, Pendekatan Kuantitatif, Kualitatif dan $R \& D i$. Bandung : CV. Alfabeta.

Sumiati \& asra 2007. Metode pembelajaran. Bandung: CV Wacana Prima

Susilana, Rudi \& Riyana Cepi. 2007. Media Pembelajaran, Hakikat Pengembangan, Pemanfaatan dan penilaian. Bandung: CV Wacana Prima

Viajani, dkk. 2013. Pengembangan Media Pembelajaran Fisika Menggunakan Macromedia Flash Pro 8 pada Pokok Bahasan Suhu dan Kalor. Jurnal Pendidikan Fisika. 1 (1) 145 